\title{
The Influence of Forest Management and Changed Hydrology on Soil Biochemical Properties in a Central-European Floodplain Forest
}

\author{
Martin Valtera ${ }^{1, *}$, Jiří Volánek ${ }^{1} \mathbb{D}$, Ladislav Holík ${ }^{1}$, Václav Pecina ${ }^{2,3} \mathbb{D}$, Jitka Novotná ${ }^{4}$, Vojtěch Slezák ${ }^{1}$ \\ and David Jư̌ička $1, *$ (iD
}

1 Department of Geology and Soil Science, Faculty of Forestry and Wood Technology, Mendel University in Brno, Zemědělská 3, 61300 Brno, Czech Republic; jiri.volanek@mendelu.cz (J.V.); ladislav.holik@mendelu.cz (L.H.); xslezak2@mendelu.cz (V.S.)

2 Department of Agrochemistry, Soil Science, Microbiology and Plant Nutrition, Faculty of AgriSciences, Mendel University in Brno, Zemědělská 1, 61300 Brno, Czech Republic; vaclav.pecina@mendelu.cz

3 Institute of Chemistry and Technology of Environmental Protection, Faculty of Chemistry, Brno University of Technology, Purkyňova 118, 61200 Brno, Czech Republic

4 Czech Geological Survey, Leitnerova 204, 60200 Brno, Czech Republic; jitka.novotna@geology.cz

* Correspondence: martin.valtera@mendelu.cz (M.V.); david.juricka@mendelu.cz (D.J.); Tel.: +420-545-134-309 (D.J.)

check for updates

Citation: Valtera, M.; Volánek, J.; Holík, L.; Pecina, V.; Novotná, J.; Slezák, V.; Juřička, D. The Influence of Forest Management and Changed Hydrology on Soil Biochemical Properties in a Central-European Floodplain Forest. Forests 2021, 12, 270. https://doi.org/10.3390/ f12030270

Academic Editor: Ivo Machar

Received: 29 January 2021

Accepted: 23 February 2021

Published: 26 February 2021

Publisher's Note: MDPI stays neutral with regard to jurisdictional claims in published maps and institutional affiliations.

Copyright: (c) 2021 by the authors. Licensee MDPI, Basel, Switzerland. This article is an open access article distributed under the terms and conditions of the Creative Commons Attribution (CC BY) license (https:// creativecommons.org/licenses/by/ $4.0 /)$.

\begin{abstract}
Anthropogenic modifications to water regimes are one of the main factors threatening the stability and existence of floodplain forests. This study presents an analysis of topsoil biogeochemistry within three floodplain forest stands with different levels of human alteration. Decreasing contents of soil organic carbon (OC) and microbial biomass were observed along the gradient from natural to plantation forest. High annual variations were observed in soil $\mathrm{N}$ contents and in microbial biomass, while comparable spatial variations were observed within the natural forest. High ground-water levels resulted in increased accumulation of available $\mathrm{Na}^{+}$and $\mathrm{SO}_{4}{ }^{2-}$ in the natural forest soil, yet the concentrations of ions were at sub-saline levels. The increasing contents of available $\mathrm{Mn}, \mathrm{SO}_{4}{ }^{2-}$ or $\mathrm{Cl}^{-}$had mostly positive effects on soil microbial activity across the sites, though the results indicate the existence of a certain ecological limit for soil microorganisms. Reintroduction of surface-water flooding should be considered in future forest and water management to promote the dilution of ions accumulated in soils and natural deposition of sediments rich in organic matter (OM) at the sites.
\end{abstract}

Keywords: ground-water; soil carbon; microbial activity; microbial biomass; sulfates; manganese; iron; C:N; salinization; climate change

\section{Introduction}

Floodplain forests represent one of the world's most important and also most endangered natural ecosystems [1-3]. Their functioning and existence have been directly influenced for centuries by anthropogenic activities that lead to their gradual transformation, loss and fragmentation around the world [4-6]. Floodplain forests are characterized by periodic fluctuations in ground-water levels, and their productivity is partly dependent on the resupply of nutrients and OM from regular floods [2,7]. Because of their high biological productivity and long-term accumulation of fluvial deposits, floodplain forests are considered a globally significant carbon sink [8-10] with a wide range of other ecosystem services [11]. Anthropogenic modifications to the water regime are one of the main factors threatening the stability and existence of floodplain forests [1,2,5,12]. Significant landscape-level management interventions, such as extensive river regulations in many European countries $[4,6]$, have significantly affected large areas of original floodplain forests, but their impacts on ecosystem functions have not been always fully explored [13]. As a result of the elimination of regular flooding following river regulations, many floodplain 
forest ecosystems have become increasingly dependent on ground-water supply of variable quantity and quality. Forest management through its direct and indirect impacts on forest structure and biomass extraction, also plays a significant role in the modification of soil nutrient cycles and OC sequestration [14]. However, little is known about the influence of forest management on floodplain forest soils $[15,16]$ and about the biochemical changes induced by alteration of the water regime (e.g., [9,16-18]).

Floodplain forest salinization is a phenomenon typical especially for semi-arid and arid [5,19] or brackish areas [20-22], where the predominant capillary rise and groundwater evaporation are the main processes of salt accumulation in soil. Under certain conditions, the process of salinization can be also expected in some inland temperate floodplains, particularly as a result anthropogenic modifications to the hydrologic cycle [23]. Increasing salinization of forest soils can lead to the limitation of tree growth and increased tree mortality and sensitivity to climate change [21]. Excessive salt accumulation in soil causes a significant decrease in microbial activity [24] and negatively affects soil fertility with both direct and indirect impacts on other soil properties [25]. Apart from $\mathrm{Na}^{+}$and $\mathrm{Cl}^{-}$, other salt elements and compounds such as sulfates $\left(\mathrm{SO}_{4}{ }^{2-}\right)$ or certain biologically active metals such as Fe and Mn can significantly accumulate from a mineral-rich Groundwater. This phenomenon is currently marginal within temperate floodplain forests of continental Europe, though may gain further attention along with the ongoing climatechange [23]. Sulfates are important constituents of anaerobic metabolism and their soil contents varies seasonally depending on atmospheric and ground-water inputs, plant uptake, OM mineralization and soil microbial activity [26]. Sulfate accumulation represents a serious environmental issue in some freshwater wetland ecosystems, as it often leads to eutrophication and under anaerobic condition to potential transformation into toxic sulphide [27]. Fe and Mn generally share similar chemical behavior in soils, which is due to their typical valence states and chemical forms [28,29]. The two metals also have a strong affinity to organic substances [30,31] and may, under certain conditions, accumulate in OM-rich soil horizons and influence soil microbial activity. Mn is a key component of the manganese-peroxidase enzyme, which is produced by fungi to break down lignin [32]. The availability of Mn to microorganisms can thus have a significant effect on the dynamics of soil OM [33]. Fe also participates in the catalytic cycle, in the process of phenolic compound degradation, concurrently with the activity of manganese peroxidases [34].

The aims of this study were (i) to investigate the impacts of management (changed forest structure and hydrology) on soil biochemical properties along the gradient of forest stands with different levels of human alteration, (ii) to assess the degree of annual changes in the biochemical properties of soils, and finally (iii) to evaluate whether the salt and sulfate accumulation of expected ground-water origin may limit microbial activity and related biochemical soil properties at the sites. We hypothesize that: (H1) The less-intensively managed forest sites will show higher contents of soil OC and total nitrogen $(\mathrm{N})$, and higher microbial biomass; $(\mathrm{H} 2)$ The evapoconcentration of mineralized ground-water leads to the accumulation of sulfates, chlorides, and $\mathrm{Na}^{+}$in the mineral topsoil; (H3) The increase in ground-water-induced soil mineral contents present a limitation for soil microbial activity.

\section{Materials and Methods}

\subsection{Study Area}

The research was conducted in the Czech Republic, Central Europe, at altitudes of 166-175 m, between the two rivers Šatava and Jihlava (Figure 1). The region is one of the warmest while precipitation poorer in the country (mean annual temperature $9.2^{\circ} \mathrm{C}$; average annual precipitation $563 \mathrm{~mm}$ [35]. The study area represents a fragmented landscape of floodplain forest that has undergone extensive modifications of water regime. The former floodplain forests are increasingly dependent on the resupply of ground-water from wider infiltration area [36]. The geology of the area is formed by Quaternary fluvial sediments (QFS), underlain by marine Neogene sediments of calcareous clays, calcareous gravels and gravel sands [37]. The underling Neogene clays form a hydrological barrier that allows the 
formation of aquifer in the above-imposed QFS. The ground-water accumulating in the area is enriched by minerals from the marine Neogene sediments [36]. Several hydrogeological surveys of ground-water in the area [37-39] revealed the concentrations of total dissolved solids (TDS) of $940-3975 \mathrm{mg} \cdot \mathrm{L}^{-1}$ at electrical conductivity of $1104-4290 \mu \mathrm{S} \cdot \mathrm{cm}^{-1}$, with the concentrations of bicarbonate $\left(\mathrm{HCO}_{3}{ }^{-}\right) 360-663 \mathrm{mg} \cdot \mathrm{L}^{-1}$, sulfate $\left(\mathrm{SO}_{4}{ }^{2-}\right) 187-1740 \mathrm{mg} \cdot \mathrm{L}^{-1}$, $\mathrm{Cl}^{-} 31-505 \mathrm{mg} \cdot \mathrm{L}^{-1}, \mathrm{Na}^{+} 36-346 \mathrm{mg} \cdot \mathrm{L}^{-1}, \mathrm{Ca}^{2+} 150-515 \mathrm{mg} \cdot \mathrm{L}^{-1}, \mathrm{Mg}^{2+} 36-227 \mathrm{mg} \cdot \mathrm{L}^{-1}$, Fe 2.6-7.8 $\mathrm{mg} \cdot \mathrm{L}^{-1}$, and $\mathrm{Mn} 0.15-2.01 \mathrm{mg} \cdot \mathrm{L}^{-1}$ (Table A1).

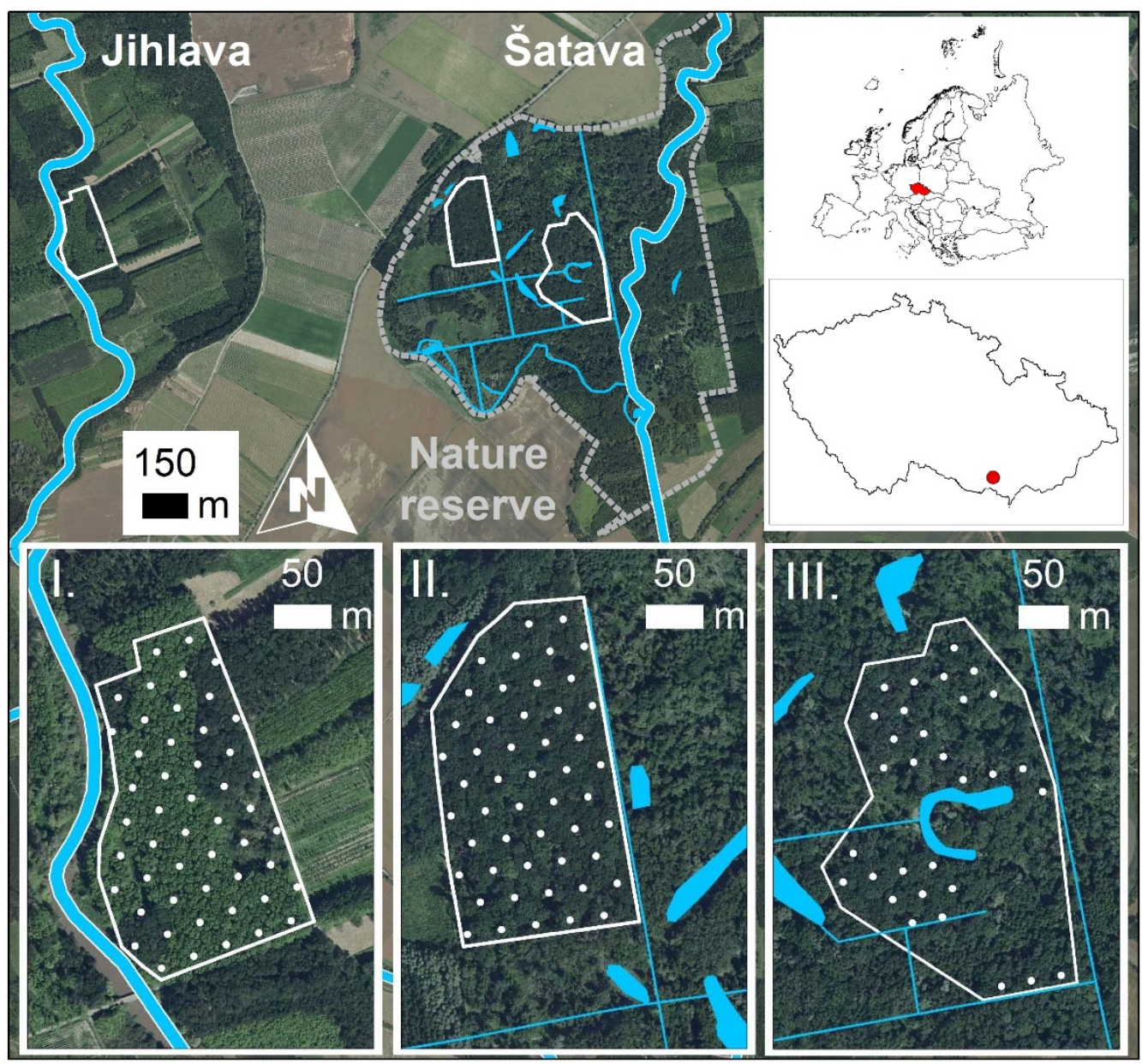

Figure 1. Location of the study area between rivers Jihlava and Šatava and the sampling design at the three study sites ((I) Bedrich, (II) Placek A, and (III) Placek B). Within the Natural Reserve, the blue polygons represent open water bodies; the lines are ditches and channels of the drainage system. The hexagonal point grid within each site indicates the geometrical centers of plots used for soil sampling.

\subsection{Study Sites}

Three forest stands dominated by common oak (Quercus robur L.) were selected along the gradient of sites with different levels of human alteration (Figure 1). The Bedrich forest site is a 70-year-old forest stand planted in rows (hereby referred as plantation forest), with the admixture of ash (Fraxinus excelsior L.) and the understory dominated by Urtica dioica L. up to 2-m tall. The area was artificially drained and stump harvesting and soil preparation are commonly used methods of reforestation practices. The soils are classified as Eutric Fluvisols according to FAO [40]. The second and the third sites are located within the Placek Forest Natural Reserve, a well-preserved but isolated relic of former floodplain forest. Although regular flooding is prevented by the construction of dikes, which also limit draining into the river, the high supply of ground-water in the area partially compensates for the absence of floods [36]. The ground-water level is regulated by 
the system of ditches (Figure 1), by which the excess water is pumped into the river. Here, two sites with moderate to minor human alteration were selected, respectively: Placek A is a 140-years old forest stand with the admixture of ash and a dense understory of dogwood (Cornus sanguinea L.), ash, and black elder (Sambucus nigra L.) situated at the periphery of the reserve (hereby, referred to as managed forest); Placek B is a partly fragmented (semi)natural stand of oak and ash more than 160-years old, with a dense regrowth of ash and dogwood in the understory, situated in the core-zone of the reserve. For the purposes of this study, only parts of the stand where mature oaks dominate the canopy were selected. Placek B has been managed extensively and left to natural succession since 1998 (hereby, referred as natural forest). The soils at Placek Forest are classified as Gleyic Fluvisols and Fluvic Gelysols according to FAO [40]. The humus forms at all three study sites were classified as Mesomull [41].

To document the ground-water chemistry, two and three samples were collected from the corresponding number of hydrogeological wells at Bedrich and Placek forests, respectively. In addition, two samples of surface water were collected from the Jihlava river, which is the only surface water at Bedrich forest, and ten samples of surface water were collected from the system of ditches and pools at Placek Forest. With the exception of well No. 3 (located to the S between Placek A and Placek B), the water chemistry was comparable between Bedrich and Placek forests, but the ground-water at Bedrich forest had higher concentrations of Fe and Mn (Table A1).

\subsection{Soil Sampling}

Soil samples were collected at points distributed in a regular hexagonal net with the spacing grid of $30 \mathrm{~m}$. At each plot, disturbed composite sample of the $0-10-\mathrm{cm}$ depth mineral soil was assembled from three sampling positions that were spaced triangularly around the central point in the distance of 4-8 m from each other. In total, 50 samples at Bedrich site and 50 samples at Placek A site were collected in June 2019. In May 2020, repeated sampling was performed at 10 of the plots at both Bedrich and Placek A sites, and another 31 plots at Placek B (Figure 1). The $2 \times 10$ plots for resampling were selected upon stratification of soil conductivity at the original 50 plots from 2019 into deciles, where always one plot of each decile was randomly selected for resampling in 2020. The composite samples from each plot were collected into plastic bags, transported to the laboratory and stored in a refrigerator at $4^{\circ} \mathrm{C}$ until analysis. The meteorological data in the days of soil sampling and the 30 preceding days are provided in Table A2.

\subsection{Laboratory Analysis}

Specific electrical conductivity (EC) was determined in a 1:5 aqueous extract of soil according to ISO 11265. The total soluble soil $\mathrm{Na}^{+}, \mathrm{Cl}^{-}$and $\mathrm{SO}_{4}{ }^{2-}$ contents were determined in a 1:5 (soil to water) extract; the $\mathrm{Na}^{+}$contents were determined by flame emission spectrometry (ISO 9964); chlorides were determined coulometrically as adsorbable organically bound halogens (ISO 9562); and $\mathrm{SO}_{4}{ }^{2-}$ was determined by isotachophoresis according to Zbíral et al. [42]. Plant-available Mn and Fe contents were determined from the Mehlich 3 extractant [43] using atomic absorption spectrometry (AAS) (ISO 5961; ISO 12020). The contents of total carbon (C) and $\mathrm{N}$ were determined by an elemental analyzer (Vario MACRO cube, Elementar, Germany). Soil samples from 2020 and selected samples from 2019 (those resampled in 2020) were also analyzed for OC and inorganic carbon (IC) contents by temperature-dependent $C$ fraction differentiation in both oxygenated and non-oxygenated atmospheres (SoliTOC, Elementar, Germany). Soil pH was determined in a 1:5 (volume fraction) suspension of soil in water according to ISO 10390. Microbial-biomass carbon $\left(\mathrm{C}_{\text {mic }}\right)$ content was determined by chloroform-fumigation- $-\mathrm{K}_{2} \mathrm{SO}_{4}$ extraction (ISO 14240-2) and spectrophotometric determination of actual oxidizable carbon [42]. Catalase activity (CA) was measured volumetrically according to Gömöryová et al. [44]. Soil basal respiration (BR) and substrate-induced respiration (SIR) were evaluated according to ISO 16072. 


\subsection{Statistical Analyses}

All statistical analyses were performed in the R statistical environment [45]. The differences among sites in particular years were tested using the Tukey's Honest Significant Difference test. The annual changes in soil characteristics were tested using the one-sided paired t-test. To fulfil the assumption on normality, data were Box-Cox transformed prior to analysis. Pearson pairwise correlations were used to describe the relationships between soil variables within each site and year on the Box-Cox transformed data. Multiple linear regression models were used to model the within-site variation in soil biological properties, such as $\mathrm{C}_{\text {mic }}$, SIR, $\mathrm{BR}$, and $\mathrm{CA}$, where the $\mathrm{EC}, \mathrm{SO}_{4}{ }^{2-}, \mathrm{Cl}^{-}, \mathrm{Na}^{+}, \mathrm{Fe}$, and Mn contents, $\mathrm{pH}$, and C: $\mathrm{N}$ were used as the explanatory variables. Model building was performed using the both-directional stepwise selection procedure based on the Akaike Information Criterion [46]. To avoid overfitting, the maximum number of two explanatory variables was used in each model. The validity of model assumptions was tested using the 'gvlma' function. The distribution of model residuals was checked visually using residual, quantilequantile, and Cook's distance plots. A model was accepted as valid only, if all the prediction terms were significant at $p<0.05$.

\section{Results}

\subsection{The Between-Site Variation in Soil Properties}

The studied soil properties mostly varied among sites (Figure 2). Both the years, lower contents of $\mathrm{C}, \mathrm{N}$, and $\mathrm{OC}$ were determined in the topsoil at Bedrich site, as compared to Placek A. In 2020, the highest C and OC contents were observed at Placek B, while the N contents did not differ significantly from Placek A. All soils showed the IC contents less than $1.4 \mathrm{~g} \mathrm{~kg}^{-1}$, indicating low contents of carbonates. The IC contents were slightly higher at Bedrich site and lower at Placek A. The soils at Bedrich site also showed significantly higher pH compared to Placek A in 2019 and compared to Placek B in 2020. In parallel, the C:N ratio was significantly lower at Bedrich site, as compared to Placek A in 2019 and lower at Placek A as compared to Placek B in 2020.

In 2019, the $\mathrm{Cl}^{-}$and $\mathrm{SO}_{4}{ }^{2-}$ contents were both significantly higher at Bedrich forest, as compared to Placek A. In 2020, however, the lowest $\mathrm{Cl}^{-}$contents were observed at Bedrich forest, with no significant difference between Placek A and Placek B. The highest $\mathrm{SO}_{4}{ }^{2-}$ contents in 2020 were observed at Placek B, with no significant difference between Bedrich forest and Placek $\mathrm{A}$, while the $\mathrm{Na}^{+}$contents gradually increased along the sequence Bedrich $<$ Placek A < Placek B. In contrast, the available Fe and Mn contents were significantly higher at Bedrich forest as compared to Placek A in both years, though the highest contents of available Fe and the lowest contents of available Mn in 2020 were at Placek B (Figure 2).

In 2019, the $\mathrm{C}_{\text {mic }}$ contents, BR and SIR were all higher in Placek A as compared to Bedrich site, while an opposite pattern was observed for the CA. In 2020, however, both the BR and CA did not differ significantly among sites, while the SIR gradually increased along the sequence of Bedrich $<$ Placek A $<$ Placek B (Figure 2). 


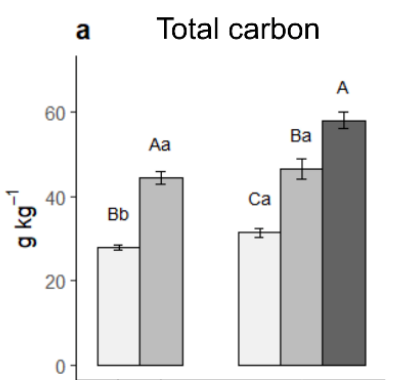

e Organic carbon

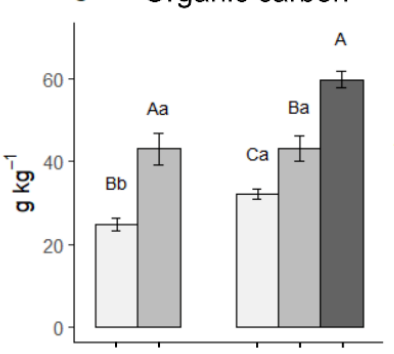

i Microbial-biomas carbon

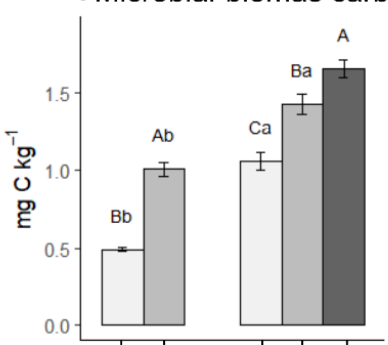

m Substrate-induced

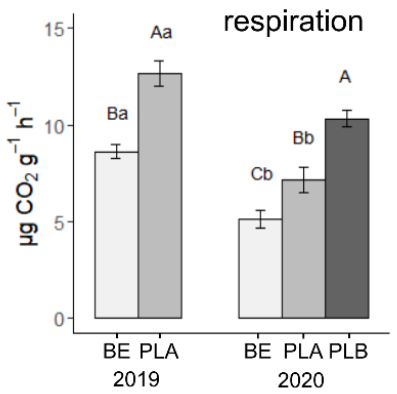

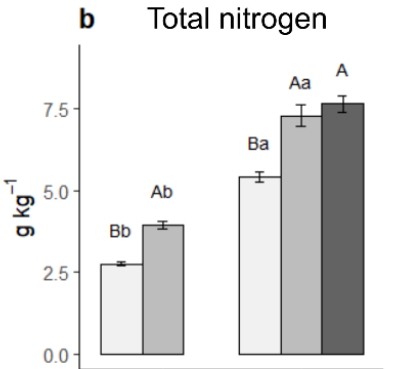
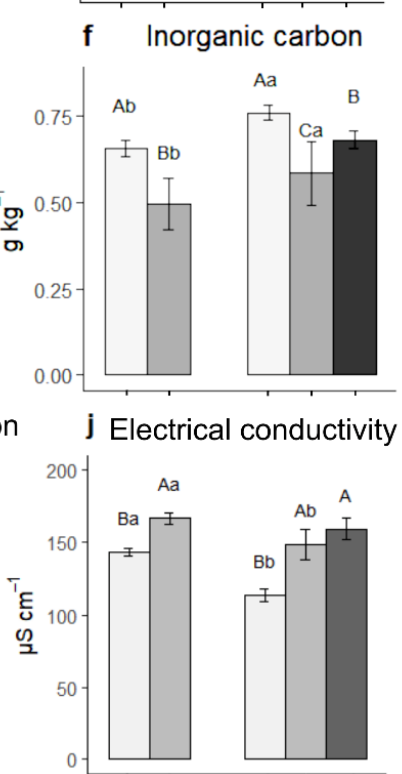

n Basal respiration

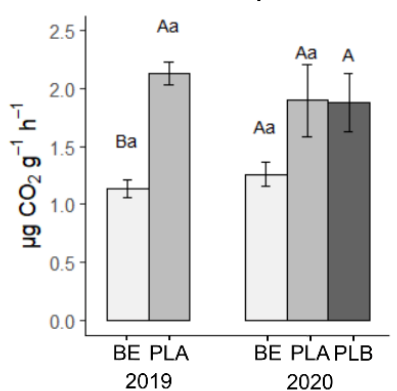


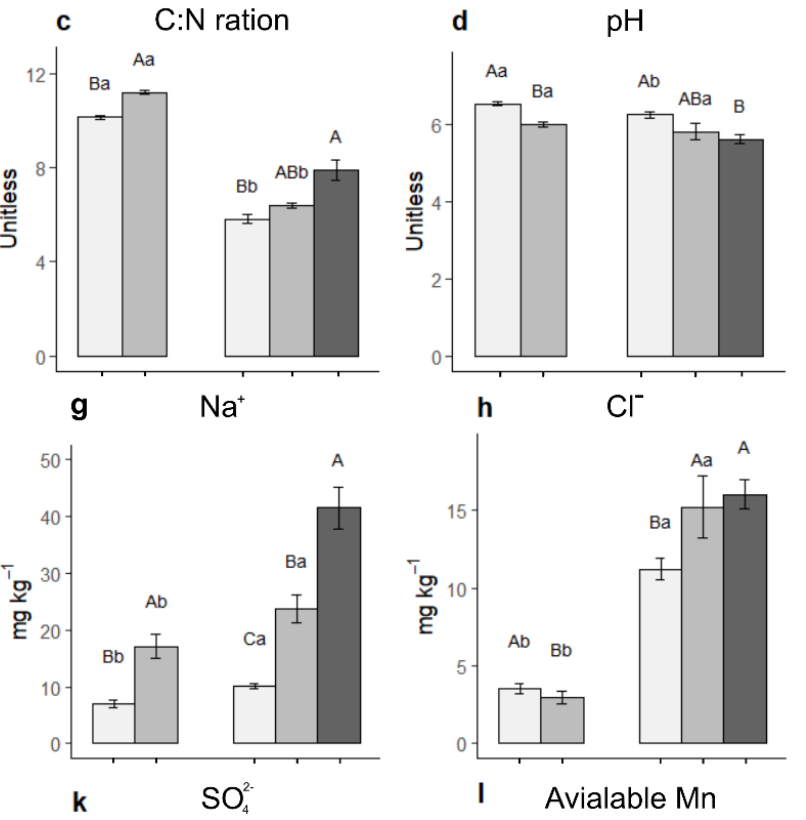

I Avialable $\mathrm{Mn}$



- Catalase activity

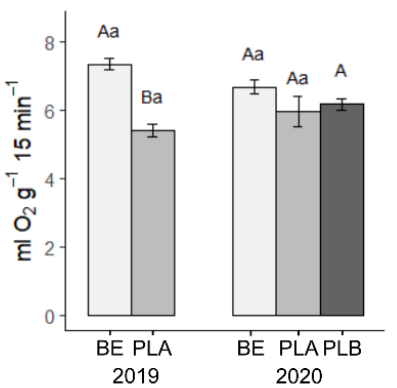

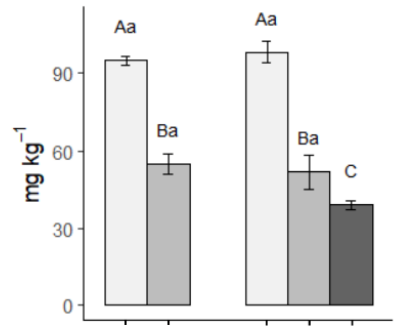

p Avialable $\mathrm{Fe}$

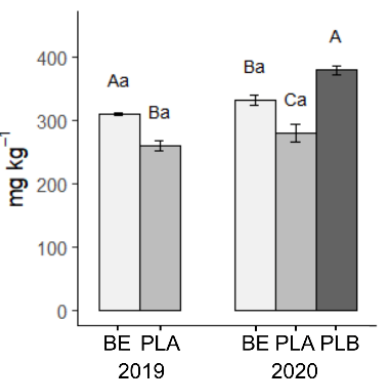

Figure 2. Summary statistics of the topsoil properties at study sites in years 2019 and 2020 (BE = Bedrich "plantation forest"; PLA = Placek A "managed forest"; PLB = Placek B "natural forest"). Different upper-case letters indicate significant differences among sites in a particular year at $p=0.05$ (the Tukey's Honest Significant Difference test); different lower-case letters indicate significant differences between years at $p=0.05$ (one-sided paired $t$-test).

\subsection{The Annual Variation in Soil Properties}

At both Bedrich and Placek A sites, the EC significantly decreased between the years 2019 and 2020. In contrast, the $\mathrm{Na}^{+}$and $\mathrm{Cl}^{-}$contents showed significant annual increases at both Bedrich and Placek A sites. The sulfate contents significantly decreased at Bedrich forest, while no significant change was observed at Placek A. The available Mn and Fe contents did not change significantly between the years at any of the sites (Figure 2). Only at Bedrich site, a significant annual increase was observed in both the $\mathrm{C}$ and OC contents, followed by a decrease in soil $\mathrm{pH}$. At Placek A, neither the OC content nor soil $\mathrm{pH}$ changed between the years. The strong annual decreases in soil C:N at Bedrich and Placek A sites were mostly due to the increases in $\mathrm{N}$ contents; at both sites, the mean $\mathrm{N}$ contents nearly doubled in 2020 as compared to 2019 , so the mean C:N decreased annually from 10.1 to 5.8 and from 11.2 to 6.4 at the Bedrich and Placek A site, respectively. This pattern was 
followed with the significant annual increase in $\mathrm{C}_{\mathrm{mic}}$ (by $115 \%$ and $41 \%$, as compared to the previous year) and the decrease in SIR (by $60 \%$ and $57 \%$, respectively) (Figure 2i,m). In contrast, the BR and CA did not change significantly between years at both sites.

\subsection{The Within-Site Variation of Soil Biological Properties}

The $C_{\text {mic }}$ and SIR were mainly predicted by soil EC, which explained $10-70 \%$ of the total variance in $C_{\text {mic }}$ and 35-76\% of the total variance in SIR (Tables 1 and 2). Only at Bedrich site in 2020, $\mathrm{C}_{\text {mic }}$ was not predicted by any valid model, except the overall strong positive correlations to soil OC and N contents (Figures A2 and A3). At Placek B, however, the responses of $C_{\text {mic }}$ and SIR to EC followed quadratic models, with apparent peaks at around $190 \mu \mathrm{S} \cdot \mathrm{cm}^{-1}$ and $210 \mu \mathrm{S} \cdot \mathrm{cm}^{-1}$, respectively, thereby culminating within the zone of plots with high C:N values (Figure 3). Across the sites and years, $\mathrm{C}_{\text {mic }}$ and SIR were significantly positively correlated (Figures A2 and A3), though at Placek A in 2019 the correlation was rather weak. The overall positive response of SIR to the increasing $\mathrm{Cl}^{-}$ contents at Placek B (Figure A3c) was partly distorted at the plots with high C:N ratio (Figure 4). Here, the 8 of 31 plots had the topsoil C:N ratio between 11.2 and 12.7 (mean 11.9), while rest of the plots had C:N ratios in between 4.5 and 6.9 (mean 6.5). This withinsite variation in soil C:N at Placek B, which was mostly due to low $\mathrm{N}$ contents at the plots with high C:N, was closely related with several other soil (bio)chemical properties, including strong positive correlations with the contents of $\mathrm{Na}^{+}, \mathrm{SO}_{4}{ }^{2-}$ and available $\mathrm{Fe}$ (Figure A3c).

In general, the availability of Mn had merely positive effects on soil microbial characteristics and was consistently the main explanatory variable for CA at both Placek A and Placek B sites, contributing to 36-63\% of the total variance (Tables 1 and 2); no valid model for CA was found at Bedrich site. In contrast, the available Fe contents had negative secondary effects on microbial characteristics, namely on $C_{\text {mic }}$ at Placek A site in 2019 (Table 1) and on BR at Placek A and Placek B sites in 2020 (Table 2). Overall, the Fe and Mn contents were significantly negatively correlated across the sites both the years (Figures $\mathrm{A} 2$ and A3). The variation in BR was regularly predicted by either the sulfate or chloride contents, with the exception of Placek A site in 2019, where both sulfates and chlorides were largely below detection limits. In 2020, however, the sulfate contents explained $75 \%$ of the variation in BR at Placek A. Sulfates and chlorides had mostly positive effects on BR, with the exception of Bedrich site in 2020, where BR was co-determined by Mn contents.

Table 1. Linear regression models of soil biological properties at the two study sites in 2019; separate statistics are provided for the prediction terms (explanatory variables), and for the whole model (indicated with ${ }^{*}$ ); $\mathrm{C}_{\text {mic }}=$ microbial-biomass carbon; $\mathrm{SIR}=$ substrate-induced respiration; $\mathrm{BR}=$ basal respiration; $\mathrm{CA}$ = catalase activity; $\mathrm{EC}=$ electrical conductivity; for comparability of regression coefficients, the data were standardized prior to analysis.

\begin{tabular}{|c|c|c|c|c|c|c|c|c|c|c|c|}
\hline Site & $\begin{array}{c}\text { Dependent } \\
\text { Variable }\end{array}$ & $\begin{array}{l}\text { Explanatory } \\
\text { Variables }\end{array}$ & Coefficient & $t$-Value & $p$-Value & $\begin{array}{l}\text { Variance } \\
\text { Explained }\end{array}$ & F-Statistics * & $p$-Value * & $R^{2 *}$ & $R^{2} \mathrm{Adj} . *$ & $\begin{array}{l}\text { Residual } \\
\mathrm{SE}^{*}\end{array}$ \\
\hline \multirow{6}{*}{ 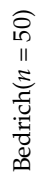 } & \multirow{2}{*}{$\mathrm{C}_{\text {mic }}$} & EC & 0.381 & 2.99 & 0.0045 & 0.15 & \multirow[t]{2}{*}{6.775} & \multirow[t]{2}{*}{0.0026} & \multirow[t]{2}{*}{0.22} & \multirow[t]{2}{*}{0.19} & \multirow[t]{2}{*}{0.892} \\
\hline & & Mn & 0.257 & 2.01 & 0.0498 & 0.07 & & & & & \\
\hline & SIR & $\mathrm{SO}_{4}^{2-}$ & 0.300 & 2.20 & 0.0326 & 0.09 & 4.834 & 0.0327 & 0.09 & 0.07 & 0.954 \\
\hline & \multirow[t]{2}{*}{$\mathrm{BR}$} & EC & 0.605 & 5.72 & $<0.0001$ & 0.38 & \multirow[t]{2}{*}{20.68} & \multirow[t]{2}{*}{$<0.0001$} & \multirow[t]{2}{*}{0.46} & \multirow[t]{2}{*}{0.44} & \multirow[t]{2}{*}{0.741} \\
\hline & & $\mathrm{Mn}$ & 0.285 & 2.69 & 0.0098 & 0.08 & & & & & \\
\hline & CA & - & - & - & - & - & - & - & - & - & - \\
\hline \multirow{8}{*}{ 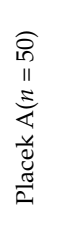 } & \multirow[t]{2}{*}{$\mathrm{C}_{\text {mic }}$} & EC & 0.404 & 3.01 & 0.0042 & 0.10 & \multirow[t]{2}{*}{5.91} & \multirow[t]{2}{*}{0.0051} & \multirow[t]{2}{*}{0.20} & \multirow{2}{*}{0.16} & \multirow{2}{*}{0.905} \\
\hline & & $\mathrm{Fe}$ & -0.324 & -2.41 & 0.0197 & 0.10 & & & & & \\
\hline & \multirow[t]{2}{*}{ SIR } & EC & 0.439 & 3.84 & 0.0004 & 0.39 & \multirow[t]{2}{*}{18.75} & \multirow[t]{2}{*}{$<0.0001$} & \multirow[t]{2}{*}{0.44} & \multirow[t]{2}{*}{0.42} & \multirow[t]{2}{*}{0.757} \\
\hline & & $\mathrm{C}: \mathrm{N}$ & 0.285 & 2.09 & 0.0421 & 0.05 & & & & & \\
\hline & \multirow[t]{2}{*}{ BR } & $\mathrm{EC}$ & 0.628 & 6.83 & $<0.0001$ & 0.48 & \multirow[t]{2}{*}{26.52} & \multirow[t]{2}{*}{$<0.0001$} & \multirow[t]{2}{*}{0.61} & \multirow[t]{2}{*}{0.59} & \multirow[t]{2}{*}{0.633} \\
\hline & & $\mathrm{Mn}$ & 0.361 & 3.92 & 0.0003 & 0.13 & & & & & \\
\hline & \multirow[t]{2}{*}{$\mathrm{CA}$} & $\mathrm{Mn}$ & 0.747 & 9.13 & $<0.0001$ & 0.63 & \multirow[t]{2}{*}{53.59} & \multirow[t]{2}{*}{$<0.0001$} & \multirow[t]{2}{*}{0.69} & 0.68 & 0.562 \\
\hline & & $\mathrm{EC}$ & 0.247 & 3.02 & 0.0041 & 0.06 & & & & & \\
\hline
\end{tabular}


Table 2. Linear regression models of soil biological properties at the three study sites in 2020; separate statistics are provided for the prediction terms (explanatory variables), and for the whole model (indicated with ${ }^{*}$ ); $\mathrm{C}_{\text {mic }}=$ microbial-biomass carbon; SIR = substrate-induced respiration; $\mathrm{BR}=$ basal respiration; $\mathrm{CA}$ = catalase activity; $\mathrm{EC}=$ electrical conductivity; for comparability of regression coefficients, the data were standardized prior to analysis.

\begin{tabular}{|c|c|c|c|c|c|c|c|c|c|c|c|}
\hline Site & $\begin{array}{c}\text { Dependent } \\
\text { Variable }\end{array}$ & $\begin{array}{c}\text { Explanatory } \\
\text { Variables }\end{array}$ & Coefficient & $t$-Value & $p$-Value & $\begin{array}{l}\text { Variance } \\
\text { Explained }\end{array}$ & F-Statistics * & $p$-Value * & $R^{2 *}$ & $R^{2} \mathrm{Adj} .{ }^{*}$ & $\begin{array}{c}\text { Residual } \\
\text { SE }^{*}\end{array}$ \\
\hline \multirow{4}{*}{ 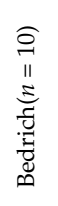 } & $\mathrm{C}_{\text {mic }}$ & - & - & - & - & - & - & - & - & - & - \\
\hline & SIR & $\begin{array}{c}\mathrm{Mn} \\
\mathrm{SO}_{4}{ }^{2-}\end{array}$ & $\begin{array}{c}0.654 \\
-0.563\end{array}$ & $\begin{array}{c}3.02 \\
-2.60\end{array}$ & $\begin{array}{l}0.0166 \\
0.0317\end{array}$ & $\begin{array}{l}0.32 \\
0.31\end{array}$ & 6.898 & 0.018 & 0.63 & 0.54 & 0.643 \\
\hline & $\mathrm{BR}$ & $\mathrm{EC}$ & 0.760 & 3.51 & 0.0067 & 0.58 & 12.3 & 0.007 & 0.58 & 0.53 & 0.650 \\
\hline & $\mathrm{CA}$ & - & - & - & - & - & - & - & - & - & - \\
\hline \multirow{4}{*}{  } & $\mathrm{C}_{\text {mic }}$ & $\begin{array}{c}\text { EC } \\
C: N\end{array}$ & $\begin{array}{l}0.722 \\
0.366\end{array}$ & $\begin{array}{l}4.60 \\
2.33\end{array}$ & $\begin{array}{l}0.0018 \\
0.0481\end{array}$ & $\begin{array}{l}0.70 \\
0.12\end{array}$ & 18.61 & $<0.0001$ & 0.82 & 0.78 & 0.446 \\
\hline & $\mathrm{BR}$ & $\begin{array}{c}\mathrm{SO}_{4}^{2-} \\
\mathrm{Fe}\end{array}$ & $\begin{array}{c}1.305 \\
-0.580\end{array}$ & $\begin{array}{c}7.21 \\
-3.21\end{array}$ & $\begin{array}{c}<0.0001 \\
0.0125\end{array}$ & $\begin{array}{l}0.75 \\
0.14\end{array}$ & 32.10 & 0.0002 & 0.89 & 0.86 & 0.353 \\
\hline & SIR & $\mathrm{EC}$ & 0.874 & 5.41 & $<0.0001$ & - & 29.24 & $<0.0001$ & 0.76 & 0.74 & 0.485 \\
\hline & CA & $\begin{array}{c}\mathrm{Mn} \\
\mathrm{SO}_{4}^{2-}\end{array}$ & $\begin{array}{l}0.919 \\
0.544\end{array}$ & $\begin{array}{l}6.21 \\
3.68 \\
\end{array}$ & $\begin{array}{c}<0.0001 \\
0.0062\end{array}$ & $\begin{array}{l}0.57 \\
0.27\end{array}$ & 21.09 & $<0.0001$ & 0.84 & 0.80 & 0.424 \\
\hline \multirow{4}{*}{ 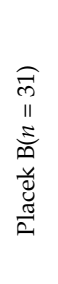 } & $\mathrm{C}_{\text {mic }}$ & $\begin{array}{c}\mathrm{EC} \\
\mathrm{EC}^{\wedge} 2\end{array}$ & $\begin{array}{c}4.814 \\
-4.604\end{array}$ & $\begin{array}{c}5.22 \\
-4.99\end{array}$ & $\begin{array}{l}<0.0001 \\
<0.0001\end{array}$ & $\begin{array}{l}0.07 \\
0.43\end{array}$ & 14.35 & $<0.0001$ & 0.50 & 0.46 & 0.721 \\
\hline & SIR & $\begin{array}{c}\mathrm{Cl}^{-} \\
\mathrm{Fe}\end{array}$ & $\begin{array}{c}0.551 \\
-0.300 \\
\end{array}$ & $\begin{array}{c}3.88 \\
-2.12 \\
\end{array}$ & $\begin{array}{l}0.0006 \\
0.0430\end{array}$ & $\begin{array}{l}0.33 \\
0.09\end{array}$ & 10.50 & 0.00037 & 0.42 & 0.38 & 0.775 \\
\hline & $\mathrm{BR}$ & $\begin{array}{c}\mathrm{EC} \\
\mathrm{EC}^{\wedge} 2\end{array}$ & $\begin{array}{c}4.410 \\
-3.860\end{array}$ & $\begin{array}{c}5.73 \\
-5.02\end{array}$ & $\begin{array}{l}<0.0001 \\
<0.0001\end{array}$ & $\begin{array}{l}0.35 \\
0.30\end{array}$ & 27.01 & $<0.0001$ & 0.65 & 0.63 & 0.601 \\
\hline & $\mathrm{CA}$ & $\begin{array}{l}\mathrm{Mn} \\
\mathrm{C}: \mathrm{N}\end{array}$ & $\begin{array}{l}0.726 \\
0.325\end{array}$ & $\begin{array}{l}4.81 \\
2.15\end{array}$ & $\begin{array}{c}<0.0001 \\
0.0399\end{array}$ & $\begin{array}{l}0.36 \\
0.09\end{array}$ & 11.59 & 0.00020 & 0.44 & 0.41 & 0.758 \\
\hline
\end{tabular}

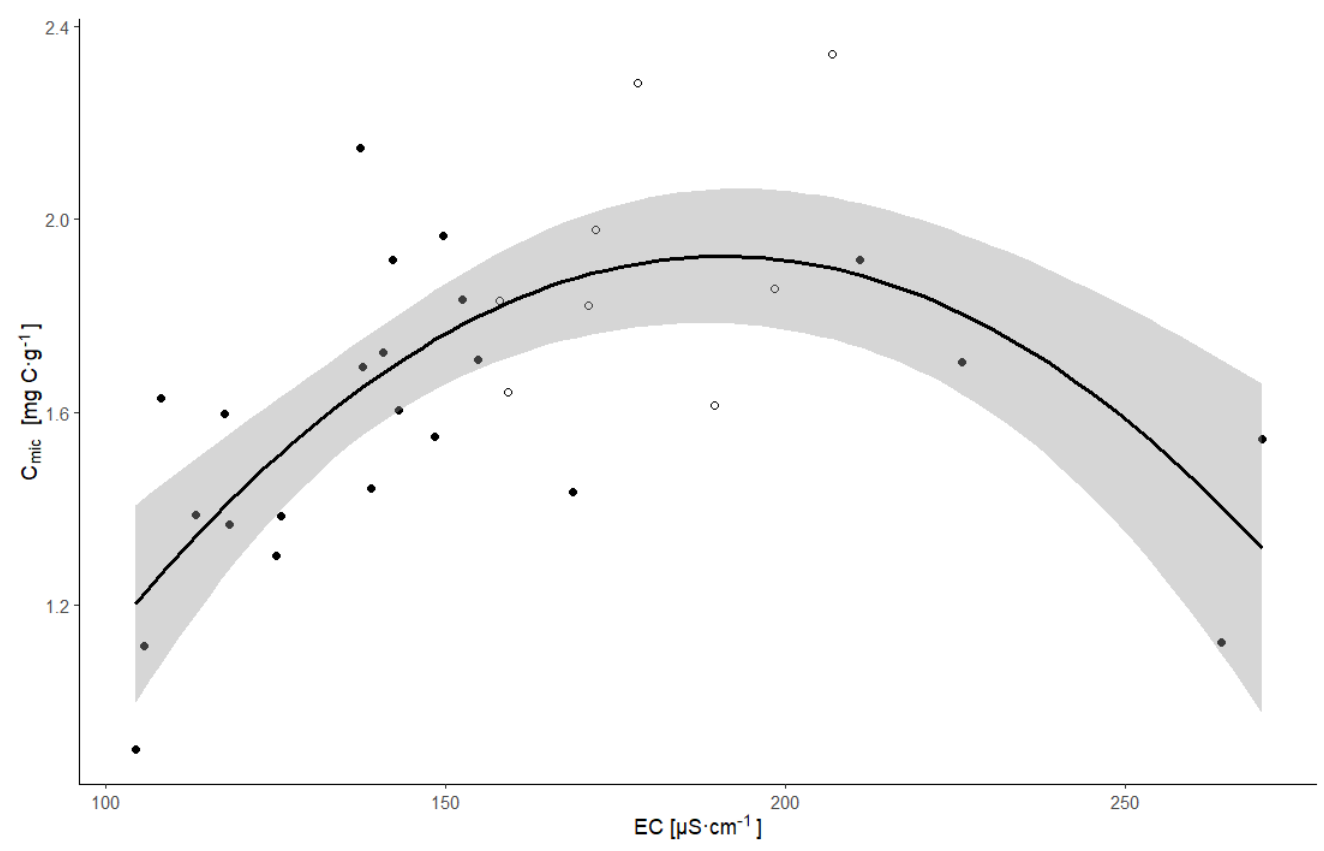

Figure 3. A quadratic regression model of the microbial-biomass carbon $\left(\mathrm{C}_{\text {mic }}\right)$ as dependent on soil electrical conductivity (EC) at Placek B site; the different levels of C:N are indicated by symbol fills (full for C:N range 4.5-6.9; hollow for C:N range 11.2-12.7). 


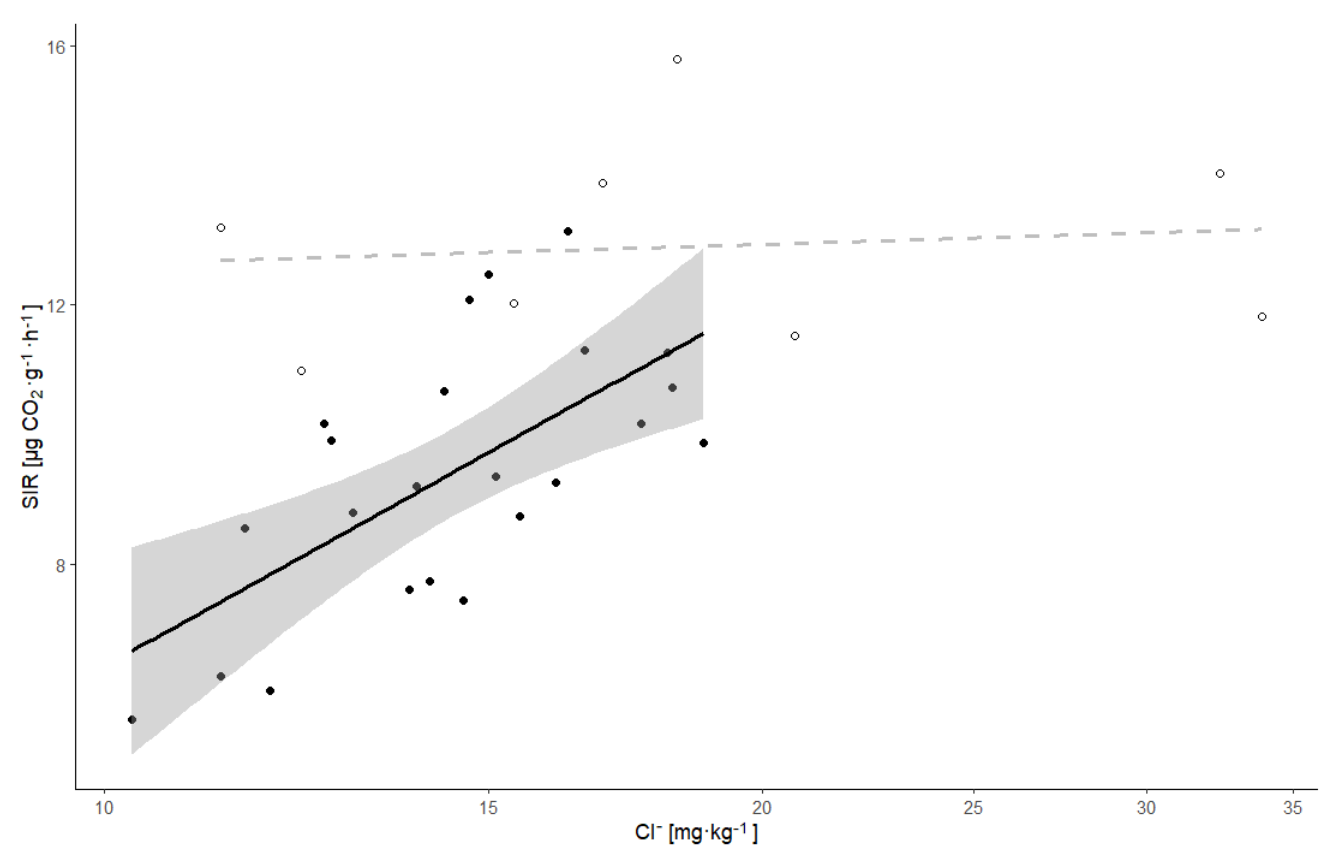

Figure 4. Linear regression models of substrate-induced respiration (SIR) as dependent on chloride contents at Placek B site, separately for the plots with different levels of C:N (full symbols + full line for C:N range 4.5-6.9; hollow symbols + dashed line for C:N range 11.2-12.7).

\section{Discussion}

\subsection{Soil OC and N Dynamics in Floodplain Forest Soils}

Results partially supported hypothesis $\mathrm{H} 1$ that the less-intensively managed sites have higher contents of soil OC and N, and higher microbial biomass. The decreasing contents of soil OC along the gradient from natural to plantation forest may indicate the decreasing sequestration of OC with increasing human alteration. The differences in soil OC contents may result from the limited litter inputs and increased OC loss following intensive biomass harvest and soil preparation. A similar finding, i.e., the loss of soil $C$ due to forest management intensification, was reported by many authors, beyond floodplain forests (e.g., [14,47-49]). At the study sites, this pattern was, however, partly related to the between- and within-site differences in soil EC and $\mathrm{Na}^{+}$contents (Figure 2; Figures A2 and A3). Therefore, we cannot decipher whether the presumed effects were more related to forest management intensification, or to other factors that are largely interlinked (i.e., intensive management techniques are not easily applicable at sites with high ground-water level). Although some authors argue that management practices such as drainage and soil preparation may facilitate $C$ sequestration in forest soils [50], this will probably not apply to floodplain forests (e.g., [9,10,15,51]). For example, Pietsch et al. [17] modelled the impact of human-induced hydrological changes (long-term elimination of springtime flooding) in an oak-dominated forests along the Dyje river, with observed significant decreases in soil $\mathrm{C}$ and N stocks. Hereby, the important role of floodplain forests as ecosystem C sink [9] may be disrupted.

In contrast, the results showed no clear pattern in the topsoil $\mathrm{N}$ contents along the gradient from natural to plantation forest (Figure 2) and rather highlighted the differences between the localities. The significant annual increase in soil N stocks, which also largely contributed to the overall decrease in the $\mathrm{C}: \mathrm{N}$ ratio in the plantation and managed forests, indicated that the observed year-on-year or seasonal dynamics may largely exceed the variation due to management or site effects. This may be due to several reasons: (i) the external $\mathrm{N}$ influx to the system through ground-water(GW) or atmospheric deposition, (ii) the release of $\mathrm{N}$ from annual litter, (iii) the seasonal dynamics in mycorrhizal $\mathrm{N}$ uptake, and/or (vi) due to a dynamic shift in soil microbial communities, such as in the fungal-to- 
bacterial ratio. High temporal variations in soil bacterial communities, microbial activity, and microbial biomass were also observed by Samaritani et al. [52] in a restored floodplain in Switzerland.

\subsection{Effects of the Water Regime on Soil Chemistry}

GW with the EC $\geq 2000 \mu \mathrm{S} \cdot \mathrm{cm}^{-1}$ is classified as moderately saline according to FAO recommendations for irrigation [53]; the threshold was exceeded in 3 out of the 10 surface-water(SW) samples at Placek Forest in 2019 (Table A1). Also, according to the U.S. Geological Survey, waters with the TDS contents $\geq 1.0 \mathrm{~g} \cdot \mathrm{L}^{-1}$ are considered saline [54]; this threshold was exceeded in 2 out of 3 SW samples and 4 out of 10 GW samples at Placek Forest, and in most of the GW samples in the legacy data (Table A1). Although the contents of the studied substances in soils did not show a significant level of salinity and the soils did not reach the criteria for saline soils [40], the contents of salts and other substances may significantly influence soil organisms even at sub-saline levels [55] (Section 4.3). The ranges of soil EC values at Placek A and Placek B sites in 2020 (Figure 2) were comparable to those observed by other authors in inland salt marshes of N-E China [56].

The highest observed soil $\mathrm{Na}^{+}$and $\mathrm{SO}_{4}{ }^{2-}$ contents at Placek B (Figure 2) might be partly related to the differences in GW levels, as compared to Bedrich forest (Table A1), and the higher contact with ponding water, as compared to Placek A (see Figure 1). Sulfates can be retained in the soil by adsorption; according to Mayer et al. [57], the adsorption of sulfates is negligible at $\mathrm{pH}>6.5$ and increases with decreasing $\mathrm{pH}$. Thus, lower soil $\mathrm{pH}$ in 2020 at Placek B (mean 5.6) might favour higher sulfate retention in soils, as compared to the plantation forest with $\mathrm{pH}$ (mean 6.2; Figure 2) close to the above-mentioned threshold. The results revealed significant annual shifts in the soil salt contents in both the re-measured stands. Substantial changes were observed in the $\mathrm{Na}^{+}$and chloride contents, while the contents of sulfates either decreased or remain unchanged (Figure 2), which partly supports hypothesis $\mathrm{H} 2$ in the presumed topsoil accumulation of salts from GW. The spring 2019 was characterized by several high-rainfall events and therefore, the soils might have been partly leached in the time of sampling. In contrast, the soil sampling in 2020 was carried out in a period without preceding intensive rainfall (Figure A1); therefore, the soils had higher salt contents. However, the values of soil conductivity annually decreased at both the sites (Figure 2), which suggest the EC may be not be a relevant indicator of soil salinity at the sub-saline levels.

Although soil salinity does not currently appear to be an imminent problem at any of the study sites, further shifts to the water balance at Placek B site could contribute to potential negative impacts on the functioning of the semi-natural ecosystem. The average air temperature in the region increased by $0.4^{\circ} \mathrm{C}$ in 1991-2010 compared to the reference period 1961-1990 [58]. In years 2021-2050, the temperatures in the region are expected to rise by $1.5^{\circ} \mathrm{C}$ as compared to the reference period [59]. Further decrease in the amount of surface and subsurface runoff due to rising evapotranspiration may result in additional increase in salt and sulfate accumulation in soils. On the other hand, prolonged ponding through increased runoff detention in Placek Forest could lead to the reduction of accumulated sulfates to toxic sulphides [27], with potential negative impacts on soil quality and forest vitality $[20,23]$.

\subsection{The Influence of Mineral Accumulation on Soil Biochemical Properties}

The $\mathrm{C}_{\text {mic }}$ contents at the studied sites (Figure $2 \mathrm{~m}$ ) well corresponded with the microbial biomass observed in other temperate floodplain forests, such as those along the river Elbe in Germany, though the total C contents were considerably lower [60] (c.f. Figure 2a). Although the results from 2020 show higher topsoil accumulation of $\mathrm{Na}^{+}$and $\mathrm{SO}_{4}{ }^{2-}$ in the natural forest (Placek B; Figure 2g,j), there were also the highest contents of $C_{\text {mic }}$ and SIR (the indices of microbial biomass; [60]). In contrast, between-site differences were not found in the case of BR and CA. This may be due to the fact that smaller microbial communities tend to be more active and use $C$ resources less efficiently [24]. These results do not 
indicate a significant effect of mineral accumulation on soil microbial activity, as expected in hypothesis $\mathrm{H} 3$, but rather the influence of forest management on substrate availability and the dynamics of soil OM.

The results revealed highest contents of available $\mathrm{Mn}$ in the topsoil of plantation forest (Figure 2), which is probably related to the higher concentrations of Mn observed in surfaceand GW a Bedrich site (Table A1). Higher contents of available Mn in soil can affect the stability of humus, lead to more intensive decomposition of soil OM and to the loss of soil OC $[61,62]$. This may partly explain the lower contents of OC and $\mathrm{N}$ in the topsoil of plantation forest (Figure $2 b, e$ ). Mn is the main component of the manganese-peroxidase enzyme [32]. The generally positive effect of the available Mn contents on the indicators of soil microbial activity across the sites (Tables 1 and 2) were apparently more important for the CA at Placek A and Placek B, where the availability of Mn might be more limiting to soil microorganisms.

The highest values of extracted Fe in the soil at Placek B are surprising due to its lower concentrations in surface- and GW (Table A1), as compared to Bedrich site; this fact may be related to the possible accumulation of Fe in association with soil OM, the contents of which were the highest at Placek B (Figure 2e,p). Fe can be translocated to the upper soil layers by fungi that facilitate the degradation of aromatic structures contained in soil OM [63]. Some fungi thereby disintegrate, for example, phenols in the so-called Fenton reaction, where iron is bound to the outer surface of hyphae $[64,65]$ and finally becomes part of the soil OM [66]. In contrast, the available Fe showed merely negative effects on the indicators of soil microbial activity, particularly on BR (Table 2), in accordance with hypothesis H3. Iron in soil forms bonds with carboxyl and phenolic groups, which are the most numerous groups in soil OM; due to differences in binding forces at higher Fe contents, microorganisms encounter greater resistance in the decomposition of soil OM [63], which can significantly reduce heterotrophic respiration. Similarly, Hobbie et al. [67] observed a negative correlation between the intensity of soil OM decomposition and the amount of exchangeable Fe in the soil sorption complex. Under anoxic conditions, available Fe may also interact and stabilize with otherwise toxic sulfides to form $\mathrm{FeS}_{\mathrm{x}}$ [27]. However, reducing conditions were not expected in the topsoil, as the waterlogged plots, characterized by different tree-species composition, were excluded from the sampling, particularly within Placek B (Figure 1, Section 2.2).

Despite the mostly positive effects of $\mathrm{Cl}^{-}$and $\mathrm{SO}_{4}{ }^{2-}$ contents on soil microbial activity (Tables 1 and 2), the quadratic responses of $\mathrm{C}_{\text {mic }}$ and SIR to soil EC (Figure 3; Table 2) at Placek $\mathrm{B}$, where the highest $\mathrm{Cl}^{-}$and $\mathrm{SO}_{4}{ }^{2-}$ contents were observed, may indicate the existence of certain ecological limits to soil microorganisms at the site, which supports hypothesis $\mathrm{H} 3$ on the ground-water-induced mineral accumulation to limit soil microorganisms. A similar "threshold" effect of EC (i.e., initial increase followed by significant decrease) on BR was observed by Saviozzi et al. [24] in a laboratory experiment with $\mathrm{NaCl}$ addition. Saline water carries many ions that can alter the predominant inorganic and biogeochemical reactions in soils and shift microbial communities that drive elemental cycles [23]. At Placek B, the plots with high vs. low C:N apparently behaved as different sub-populations in response to EC and the $\mathrm{Cl}^{-}$contents (Figures 3 and 4). This may suggest some adaptation of soil microbial communities to specific environmental conditions, such as increasing ion contents, which was apparently related to the shift in soil N dynamics.

\section{Conclusions}

In studied floodplain forest soils, the intensity of human alteration seems to have significant negative effects on OC contents and microbial biomass. However, it is not easy to decipher whether the presumed effects were more related to forest management or to changed hydrology, as these factors are largely interlinked. The limited contact with fresh waters and the increasing dependence on GW supply enhance the accumulation of $\mathrm{Na}^{+}$and $\mathrm{SO}_{4}{ }^{2-}$ in soil. The indices of soil microbial activity were strongly positively 
related to the contents of available $\mathrm{Mn}$, particularly at the sites with lower Mn availability in soils. Although the concentrations of ions remained at sub-saline levels, the indices of microbial biomass suggested the existence of certain ecological limits for soil microorganisms. Soil salinity does not currently appear to be an imminent problem in any of the studied sites. With the ongoing climate change and further shifts in the ecosystem water balance, however, the decreasing volume of surface and subsurface runoff may increase the accumulation of salts and sulfates in soils up to a level that induces physiological stress to soil or plant communities. Reintroduction of SW flooding should be considered a key constituent of future forest and water management to promote the dilution of ions accumulated in soils and natural deposition of OM-rich sediments at the sites.

The studied soils showed surprising temporal variation in the $\mathrm{N}$ contents, $\mathrm{C}: \mathrm{N}$, and microbial biomass. Even at a single site, the plots apparently split into two distinct subpopulations based on the soil C:N ratio. Such phenomena are poorly understood and rarely mentioned in scientific literature. Complex biogeochemical interactions in soils of floodplain forests with altered hydrology require further research, as our better understanding of these processes is of crucial importance for proper conservation and management of these valuable and threatened ecosystems.

Author Contributions: Conceptualization, J.N. and D.J.; methodology, M.V., D.J., J.V. and L.H.; validation, M.V., J.V. and L.H.; formal analysis, M.V.; investigation, M.V., J.V., L.H., V.S. and D.J.; data curation, J.V. and D.J.; writing-original draft preparation, M.V., J.V., L.H. and V.P.; writing-review and editing, M.V., J.V., L.H. and D.J.; visualization, M.V., D.J.; project administration, D.J.; funding acquisition, D.J. All authors have read and agreed to the published version of the manuscript.

Funding: The research was financed from the internal grant of Mendel University in Brno, project IGA LDF_TP_2019014. The contribution of V. Pecina was supported by the project of Ministry of Education, Youth, and Sports of the Czech Republic FCH-S-20-6446.

Institutional Review Board Statement: Not applicable.

Informed Consent Statement: Not applicable.

Data Availability Statement: The data presented in this study are available on request from the corresponding authors, or online here: https:/ /ugp.ldf.mendelu.cz/wcd/w-ldf-ugp/soubory/dataprojekty/soil-data-all.csv.

Acknowledgments: We thank to the students Tomáš Kaplánek, Jiří Kadlec, Ondřej Krutil, Petra Jablonická, Kateřina Sedláčková, Soham Bassu, and Gabriela Tomášová for their assistance in the field and in the laboratory. We acknowledge the three anonymous reviewers, which comments significantly helped to improve quality of the paper. We are grateful to Josef Klein and Lesy České republiky, s. p. for their information support and for enabling research in the area.

Conflicts of Interest: The authors declare no conflict of interest.

\section{Appendix A}

Table A1. The data on surface-water (SW) and ground-water (GW) chemistry in the area of Placek (PL) Forest Reserve and Bedrich (BE) forest; EC = electrical conductivity; TDS = total dissolved solids, and the GW level depth in the time of sampling. The legacy data are provided with references; without references are the original data of samples collected in May 2019; n.a. = not analyzed.

\begin{tabular}{|c|c|c|c|c|c|c|c|c|c|c|c|c|c|c|}
\hline Site & Water & Sample & $\mathrm{pH}$ & $\begin{array}{c}\mathrm{EC} \\
\mu \mathrm{S} \cdot \mathrm{cm}^{-1}\end{array}$ & $\begin{array}{c}\text { TDS } \\
\mathrm{mg} \cdot \mathrm{L}^{-1}\end{array}$ & $\begin{array}{l}\mathrm{HCO}_{3}^{-} \\
\mathrm{mg} \cdot \mathrm{L}^{-1}\end{array}$ & $\begin{array}{l}\mathrm{SO}_{4}^{2-} \\
\mathrm{mg} \cdot \mathrm{L}^{-1}\end{array}$ & $\begin{array}{c}\mathrm{Cl}^{-} \\
\mathrm{mg} \cdot \mathrm{L}^{-1}\end{array}$ & $\begin{array}{c}\mathrm{Na}^{+} \\
\mathrm{mg} \cdot \mathrm{L}^{-1}\end{array}$ & $\begin{array}{c}\mathrm{Ca}^{2+} \\
\mathrm{mg} \cdot \mathrm{L}^{-1}\end{array}$ & $\begin{array}{c}\mathrm{Mg}^{2+} \\
\mathrm{mg} \cdot \mathrm{L}^{-1}\end{array}$ & $\begin{array}{c}\mathrm{Fe} \\
\mathrm{mg} \cdot \mathrm{L}^{-1}\end{array}$ & $\begin{array}{c}\mathrm{Mn} \\
\mathrm{mg} \cdot \mathrm{L}^{-1}\end{array}$ & $\begin{array}{c}\text { Depth } \\
\mathbf{m}^{*}\end{array}$ \\
\hline \multirow{8}{*}{ PL } & GW & ČGS (2014) & 7.06 & 1160 & 940 & 360 & 210 & 94 & 48 & 150 & 41 & 4.60 & 1.50 & n.a. \\
\hline & GW & Novotná (2014) & 7.25 & 4290 & 3975 & 663 & 1740 & 505 & 346 & 515 & 227 & 5.25 & 0.15 & n.a. \\
\hline & GW & Franzová (1988) & 7.14 & 1178 & 1158 & 482 & 350 & 27 & 36 & 183 & 70 & 2.56 & 0.24 & n.a. \\
\hline & GW & Franzová (1988) & 7.12 & 1578 & 1500 & 543 & 460 & 45 & 108 & 247 & 87 & 3.97 & 0.45 & n.a. \\
\hline & GW & Franzová (1988) & 6.91 & 1671 & 1752 & 525 & 503 & 69 & 102 & 263 & 85 & 7.27 & 0.61 & n.a. \\
\hline & GW & Franzová (1988) & 7.00 & 1630 & 1423 & 505 & 390 & 57 & 142 & 263 & 55 & 5.68 & 2.01 & n.a. \\
\hline & GW & Franzová (1988) & 7.01 & 1104 & 976 & 436 & 187 & 31 & 92 & 180 & 36 & 8.69 & 1.59 & n.a. \\
\hline & GW & Franzová (1988) & 7.18 & 1179 & 1072 & 412 & 285 & 36 & 85 & 203 & 36 & 7.81 & 1.81 & n.a. \\
\hline
\end{tabular}


Table A1. Cont.

\begin{tabular}{|c|c|c|c|c|c|c|c|c|c|c|c|c|c|c|}
\hline Site & Water & Sample & $\mathrm{pH}$ & $\begin{array}{c}\text { EC } \\
\mu \mathrm{S} \cdot \mathrm{cm}^{-1}\end{array}$ & $\begin{array}{c}\text { TDS } \\
\mathrm{mg} \cdot \mathrm{L}^{-1}\end{array}$ & $\begin{array}{l}\mathrm{HCO}_{3}{ }^{-} \\
\mathrm{mg} \cdot \mathrm{L}^{-1}\end{array}$ & $\begin{array}{l}\mathrm{SO}_{4}^{2-} \\
\mathrm{mg} \cdot \mathrm{L}^{-1}\end{array}$ & $\begin{array}{c}\mathrm{Cl}^{-} \\
\mathrm{mg} \cdot \mathrm{L}^{-1}\end{array}$ & $\begin{array}{c}\mathrm{Na}^{+} \\
\mathbf{m g} \cdot \mathbf{L}^{-1}\end{array}$ & $\begin{array}{c}\mathrm{Ca}^{2+} \\
\mathrm{mg} \cdot \mathrm{L}^{-1}\end{array}$ & $\begin{array}{c}\mathrm{Mg}^{2+} \\
\mathrm{mg} \cdot \mathrm{L}^{-1}\end{array}$ & $\begin{array}{c}\mathrm{Fe} \\
\mathrm{mg} \cdot \mathrm{L}^{-1}\end{array}$ & $\begin{array}{c}\mathrm{Mn} \\
\mathrm{mg} \cdot \mathrm{L}^{-1}\end{array}$ & $\begin{array}{c}\text { Depth } \\
\text { m* }\end{array}$ \\
\hline \multirow{4}{*}{ PL } & GW & Franzová (1988) & 7.18 & 1179 & 1072 & 412 & 285 & 36 & 85 & 203 & 36 & 7.81 & 1.81 & n.a. \\
\hline & GW & PL1 & 6.70 & 6890 & 5,238 & 683 & 1590 & 1420 & 348 & 879 & 309 & $<0.10$ & 1.36 & 0.41 \\
\hline & GW & PL3 & 6.90 & 1430 & 1198 & 453 & 352 & 78 & 30 & 197 & 78 & $<0.10$ & 0.19 & 0.70 \\
\hline & GW & PL4 & 7.05 & 1230 & 973 & 459 & 151 & 106 & 54 & 144 & 52 & 0.12 & 0.29 & 0.79 \\
\hline \multirow{2}{*}{$\mathrm{BE}$} & GW & BE 1 & 6.81 & 1040 & 820 & 358 & 166 & 75 & 34 & 127 & 43 & 5.68 & 1.68 & 3.33 \\
\hline & GW & BE 2 & 6.68 & 1420 & 1074 & 414 & 212 & 150 & 55 & 166 & 57 & 5.24 & 3.80 & 3.00 \\
\hline \multirow{10}{*}{ PL } & SW & PL 101 & 7.34 & 920 & 698 & 314 & 111 & 81 & 46 & 102 & 32 & $<0.10$ & $<0.05$ & - \\
\hline & SW & PL 102 & 7.77 & 1290 & 1044 & 529 & 131 & 110 & 60 & 150 & 57 & $<0.10$ & $<0.05$ & - \\
\hline & SW & PL 103 & 7.26 & 2880 & 2,230 & 671 & 557 & 355 & 206 & 323 & 112 & $<0.10$ & $<0.05$ & - \\
\hline & SW & PL 104 & 7.58 & 2400 & 1889 & 549 & 542 & 260 & 126 & 291 & 108 & 0.14 & 1.28 & - \\
\hline & SW & PL 105 & 7.04 & 1000 & 773 & 350 & 118 & 90 & 51 & 117 & 34 & $<0.10$ & 0.15 & - \\
\hline & SW & PL 106 & 7.07 & 820 & 620 & 243 & 125 & 77 & 45 & 85 & 22 & 0.13 & 0.22 & - \\
\hline & SW & PL 107 & 7.31 & 920 & 715 & 314 & 106 & 99 & 49 & 104 & 30 & $<0.10$ & $<0.05$ & - \\
\hline & SW & PL 108 & 7.49 & 2070 & 1583 & 470 & 474 & 200 & 107 & 228 & 102 & $<0.10$ & $<0.05$ & - \\
\hline & SW & PL 109 & 7.35 & 1200 & 930 & 375 & 181 & 117 & 58 & 140 & 46 & $<0.10$ & $<0.05$ & - \\
\hline & SW & PL 110 & 7.24 & 830 & 603 & 240 & 104 & 80 & 49 & 85 & 22 & $<0.10$ & 0.17 & - \\
\hline \multirow{2}{*}{$\mathrm{BE}$} & SW & BE 101 & 7.77 & 630 & 435 & 129 & 105 & 60 & 37 & 50 & 23 & $<0.10$ & 0.05 & - \\
\hline & SW & BE 102 & 7.59 & 620 & 428 & 126 & 104 & 59 & 37 & 48 & 22 & $<0.10$ & $<0.05$ & - \\
\hline
\end{tabular}

${ }^{*}$ Measured vertically from the water level to the soil surface; altitude differences between the zero levels of the hydrogeological wells and the soil surfaces across the corresponding study sites were $\leq 1.0 \mathrm{~m}$.



Figure A1. Meteorological conditions in the study area during the day plus the 30 days preceding soil sampling in 2019 and 2020; the bars show daily precipitation; the lines show daily mean temperatures.

Table A2. Meteorological data from the nearest climatic station to the study area during the years of soil sampling (source: the Czech Hydrometeorological Institute).

\begin{tabular}{ccccc}
\hline & \multicolumn{2}{c}{ Average Temperature $\left({ }^{\circ} \mathbf{C}\right)$} & \multicolumn{2}{c}{ Total Precipitation $(\mathbf{m m})$} \\
\hline Month/Year & $\mathbf{2 0 1 9}$ & $\mathbf{2 0 2 0}$ & $\mathbf{2 0 1 9}$ & $\mathbf{2 0 2 0}$ \\
January & 0.3 & 0.1 & 32.1 & 12.1 \\
February & 2.3 & 5.2 & 11.2 & 26.4 \\
March & 7.1 & 5.8 & 14.9 & 22.6 \\
April & 11.8 & 10.5 & 20.6 & 7.2 \\
May & 12.7 & 13.1 & 93.5 & 227.8 \\
June & 22.5 & 18.2 & 96.9 & 69.8 \\
July & 20.5 & 19.5 & 75.8 & 69.0 \\
August & 20.9 & 20.7 & 65.4 & 83.8 \\
September & 14.8 & 15.2 & 52.3 & 79.2 \\
October & 10.1 & 10.4 & 32.8 & 24.4 \\
November & 7.4 & 4.9 & 38.6 & 34.3 \\
December & 2.2 & 2.9 & 47.9 & $\mathbf{7 3 1 . 5}$ \\
January-December & $\mathbf{1 1 . 0}$ & $\mathbf{1 0 . 5}$ & $\mathbf{5 8 2 . 0}$ &
\end{tabular}



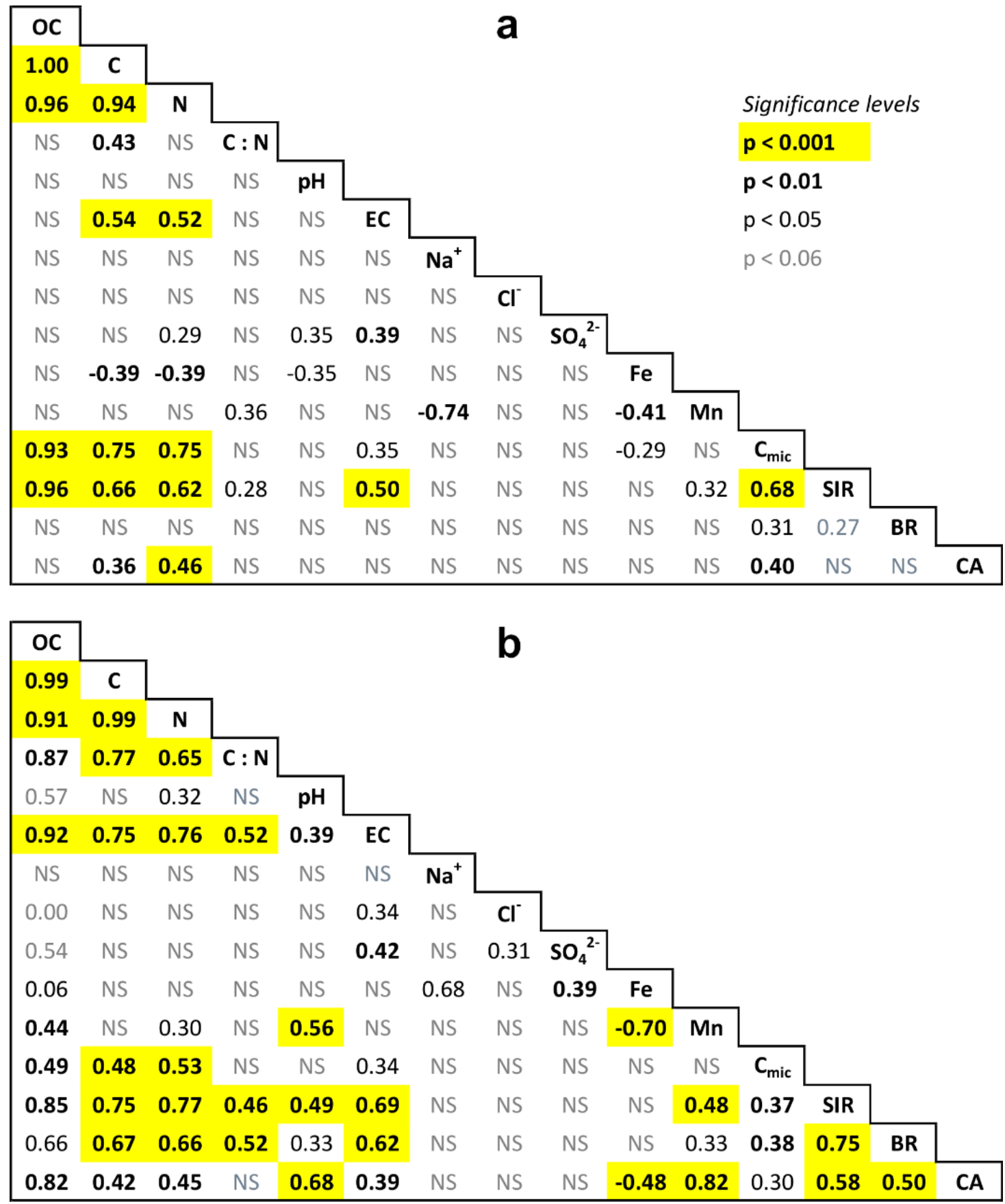

Figure A2. Correlation matrices (Pearson correlation coefficients) of the Box-Cox transformed soil data at (a) Bedrich and (b) Placek A sites in 2019; OC = organic carbon; $\mathrm{C}=$ total carbon; $\mathrm{N}=$ total nitrogen; $\mathrm{EC}=$ electrical conductivity; $\mathrm{C}_{\mathrm{mic}}=$ microbial-biomass carbon; $\mathrm{SIR}=$ substrate-induced respiration; $\mathrm{BR}=$ basal respiration; $\mathrm{CA}=$ catalase activity; $\mathrm{NS}=$ no significant correlation. 

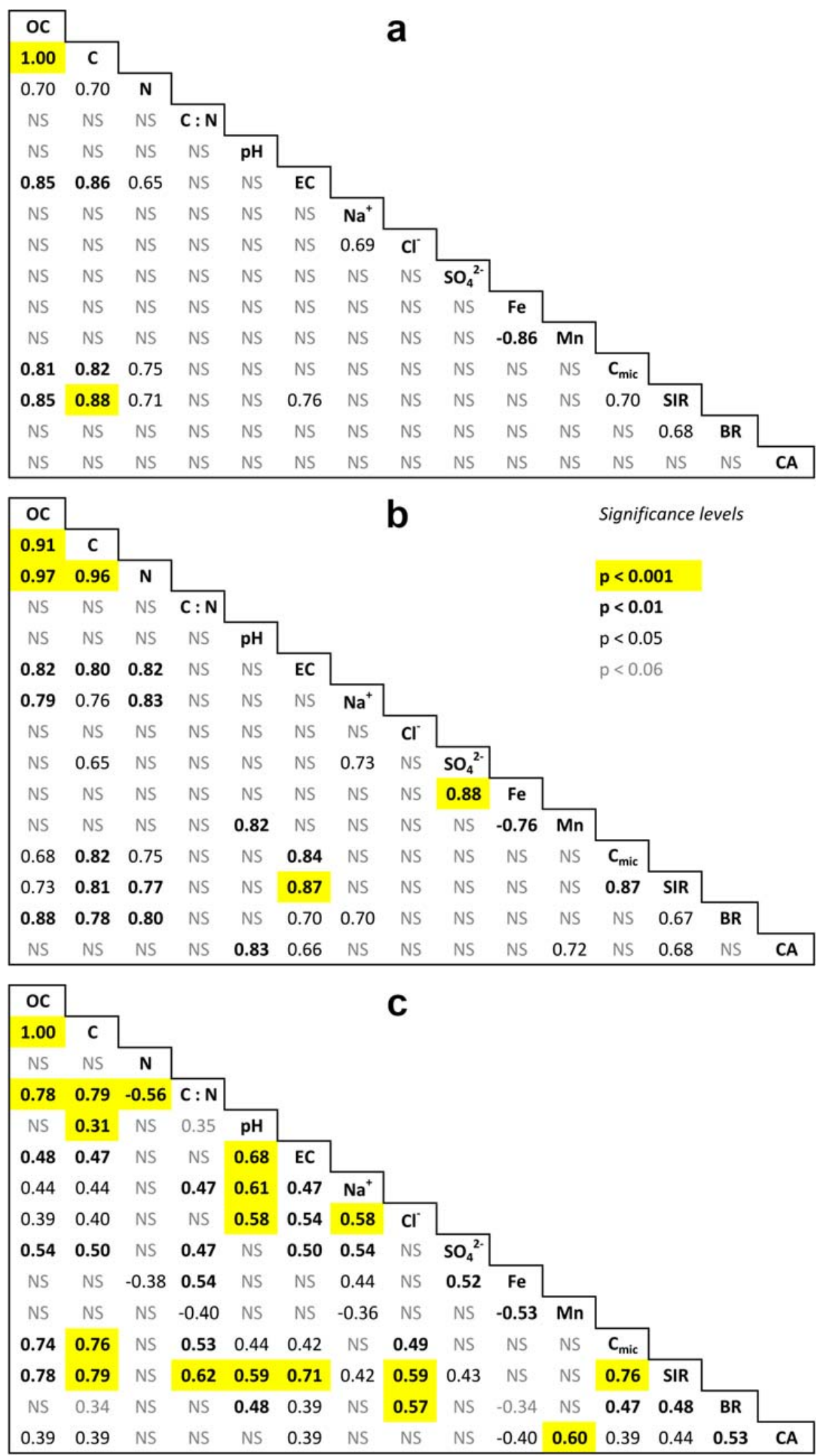

Figure A3. Correlation matrices (Pearson correlation coefficients) of the Box-Cox transformed soil data at (a) Bedrich, (b) Placek A, and (c) Placek B sites in 2020; OC = organic carbon; $\mathrm{C}=$ total carbon; $\mathrm{N}=$ total nitrogen; $\mathrm{EC}=$ electrical conductivity; $\mathrm{C}_{\text {mic }}=$ microbial-biomass carbon; $\mathrm{SIR}=$ substrate-induced respiration; $\mathrm{BR}=$ basal respiration; $\mathrm{CA}=$ catalase activity; NS = no significant correlation. 


\section{References}

1. Oswalt, S.N.; King, S.L. Channelization and floodplain forests: Impacts of accelerated sedimentation and valley plug formation on floodplain forests of the Middle Fork Forked Deer River, Tennessee, USA. For. Ecol. Manag. 2005, 215, 69-83. [CrossRef]

2. Tockner, K.; Bunn, S.; Gordon, C.; Naiman, J.; Robert, P.Q.; Gerry, A.; Stanford, J. Flood plains: Critically threatened ecosystems. In Aquatic Ecosystems. Trends and Global Prospects; Polunin, N.V.C., Ed.; Cambridge University Press: Cambridge, UK, 2008; pp. 45-61. ISBN 9780521833271.

3. Kowalska, N.; Šigut, L.; Stojanović, M.; Fischer, M.; Kyselova, I.; Pavelka, M. Analysis of floodplain forest sensitivity to drought. Philos. Trans. R. Soc. B Biol. Sci. 2020, 375, 20190518. [CrossRef]

4. Pautou, G.; Décamps, H.; Fortuné, M.; Gazelle, F. Historical influence of man on the riparian dynamics of a fluvial landscape. Landsc. Ecol. 1988, 1, 163-173. [CrossRef]

5. Nilsson, C.; Berggren, K. Alterations of Riparian Ecosystems Caused by River Regulation. BioScience 2000, 50, 783-792. [CrossRef]

6. Schindler, M.; Jungmann, L.; Donath, T.W.; Ludewig, K. Influence of flooding duration and aeration on saplings of ten hardwood floodplain forest species. PLoS ONE 2020, 15, e0234936. [CrossRef] [PubMed]

7. Gallardo, A. Spatial Variability of Soil Properties in a Floodplain Forest in Northwest Spain. Ecosystems 2003, 6, 564-576. [CrossRef]

8. Acosta, M.; Darenova, E.; Dušek, J.; Pavelka, M. Soil carbon dioxide fluxes in a mixed floodplain forest in the Czech Republic. Eur. J. Soil Biol. 2017, 82, 35-42. [CrossRef]

9. Sutfin, N.A.; Wohl, E.E.; Dwire, K.A. Banking carbon: A review of organic carbon storage and physical factors influencing retention in floodplains and riparian ecosystems. Earth Surf. Process. Landf. 2015, 41, 38-60. [CrossRef]

10. Ricker, M.C.; Lockaby, B.G. Soil Organic Carbon Stocks in a Large Eutrophic Floodplain Forest of the Southeastern Atlantic Coastal Plain, USA. Wetlands 2015, 35, 291-301. [CrossRef]

11. Pechanec, V.; Machar, I.; Sterbova, L.; Prokopova, M.; Kilianova, H.; Chobot, K.; Cudlin, P. Monetary Valuation of Natural Forest Habitats in Protected Areas. Forests 2017, 8, 427. [CrossRef]

12. Stromberg, J.C.; Tiller, R.; Richter, B. Effects of Groundwater Decline on Riparian Vegetation of Semiarid Regions: The San Pedro, Arizona. Ecol. Appl. 1996, 6, 113-131. [CrossRef]

13. Machar, I.; Hager, H.; Pechanec, V.; Kulhavy, J.; Mindas, J. Floodplain Forests-Key Forest Ecosystems for Maintaining and Sustainable Management of Water Resources in Alluvial Landscape. In Management of Water Resources in Poland; Zeleňáková, M., Kubiak-Wójcicka, K., Negm, A., Eds.; Springer International Publishing: Cham, Switzerland, 2019; pp. 249-274.

14. Achat, D.L.; Fortin, M.; Landmann, G.; Ringeval, B.; Augusto, L. Forest soil carbon is threatened by intensive biomass harvesting. Sci. Rep. 2015, 5, 15991. [CrossRef] [PubMed]

15. Cseh, V.; Kiss, M.; Tanács, E. Carbon sequestration of floodplain forests: A case study from Hungary, Maros river valley. Tiscia 2014, 40, 3-10.

16. Lininger, K.B.; Polvi, L.E. Evaluating floodplain organic carbon across a gradient of human alteration in the boreal zone. Geomorphology 2020, 370, 107390. [CrossRef]

17. Pietsch, S.A.; Hasenauer, H.; Kučera, J.; Čermák, J. Modeling effects of hydrological changes on the carbon and nitrogen balance of oak in floodplains. Tree Physiol. 2003, 23, 735-746. [CrossRef]

18. Kuzmina, Z.V.; Treshkin, S.E.; Karimova, T.Y. Effects of river flow regulation and climate fluctuations on dynamic changes in the terrestrial ecosystems of the Lower Volga delta and floodplain. Arid. Ecosyst. 2015, 5, 230-242. [CrossRef]

19. Goenster-Jordan, S.; Jannoura, R.; Jordan, G.; Buerkert, A.; Joergensen, R.G. Spatial variability of soil properties in the floodplain of a river oasis in the Mongolian Altay Mountains. Geoderma 2018, 330, 99-106. [CrossRef]

20. Noe, G.B.; Krauss, K.W.; Lockaby, B.G.; Conner, W.H.; Hupp, C.R. The effect of increasing salinity and forest mortality on soil nitrogen and phosphorus mineralization in tidal freshwater forested wetlands. Biogeochemistry 2013, 114, 225-244. [CrossRef]

21. Wang, W.; McDowell, N.G.; Ward, N.D.; Indivero, J.; Gunn, C.; Bailey, V.L. Constrained tree growth and gas exchange of seawater-exposed forests in the Pacific Northwest, USA. J. Ecol. 2019, 107, 2541-2552. [CrossRef]

22. Yabusaki, S.B.; Myers-Pigg, A.N.; Ward, N.D.; Waichler, S.R.; Sengupta, A.; Hou, Z.; Chen, X.; Fang, Y.; Duan, Z.; Serkowski, J.A.; et al. Floodplain Inundation and Salinization from a Recently Restored First-Order Tidal Stream. Water Resour. Res. 2020, 56. [CrossRef]

23. Herbert, E.R.; Boon, P.; Burgin, A.J.; Neubauer, S.C.; Franklin, R.B.; Ardón, M.; Hopfensperger, K.N.; Lamers, L.P.M.; Gell, P. A global perspective on wetland salinization: Ecological consequences of a growing threat to freshwater wetlands. Ecosphere 2015, 6, art206. [CrossRef]

24. Saviozzi, A.; Cardelli, R.; di Puccio, R. Impact of Salinity on Soil Biological Activities: A Laboratory Experiment. Commun. Soil Sci. Plant Anal. 2011, 42, 358-367. [CrossRef]

25. Machado, R.M.A.; Serralheiro, R.P.; Machado, R.M.A.; Serralheiro, R.P. Soil Salinity: Effect on Vegetable Crop Growth. Management Practices to Prevent and Mitigate Soil Salinization. Horticulturae 2017, 3, 30. [CrossRef]

26. Eriksen, J.; Murphy, M.D.; Schnug, E. The Soil Sulphur Cycle. In Sulphur in Agroecosystems; Schnug, E., Ed.; Springer: Dordrecht, The Netherlands, 1998; pp. 39-73.

27. Lamers, L.P.; Dolle, G.E.T.; Berg, S.T.V.D.; van Delft, S.P.; Roelofs, J.G. Differential responses of freshwater wetland soils to sulphate pollution. Biogeochemistry 2001, 55, 87-101. [CrossRef] 
28. Loeppert, R.H.; Inskeep, W.P. Iron. In Methods of Soil Analysis, Part 3: Chemical Methods; Sparks, D.L., Page, A.L., Helmke, P.A., Loeppert, R.H., Soltanpour, P.N., Tabatabai, M.A., Johnston, C.T., Sumner, M.E., Eds.; Soil Science Society of America and American Society of Agronomy: Madison, WI, USA, 1996; pp. 639-664.

29. Gambrell, R.P. Manganese. In Methods of Soil Analysis, Part 3: Chemical Methods; Sparks, D.L., Page, A.L., Helmke, P.A., Loeppert, R.H., Soltanpour, P.N., Tabatabai, M.A., Johnston, C.T., Sumner, M.E., Eds.; Soil Science Society of America and American Society of Agronomy: Madison, WI, USA, 1996; pp. 665-682.

30. Hernandez, L.; Probst, A.; Probst, J.L.; Ulrich, E. Heavy metal distribution in some French forest soils: Evidence for atmospheric contamination. Sci. Total Environ. 2003, 312, 195-219. [CrossRef]

31. Norouzi, M.; Ramezanpour, H. Effect of Fire on Chemical Forms of Iron and Manganese in Forest Soils of Iran. Environ. Forensics 2013, 14, 169-177. [CrossRef]

32. Sun, T.; Cui, Y.; Berg, B.; Zhang, Q.; Dong, L.; Wu, Z.; Zhang, L. A test of manganese effects on decomposition in forest and cropland sites. Soil Biol. Biochem. 2019, 129, 178-183. [CrossRef]

33. Berg, B.; Davey, M.P.; de Marco, A.; Emmett, B.; Faituri, M.; Hobbie, S.E.; Johansson, M.-B.; Liu, C.; McClaugherty, C.; Norell, L.; et al. Factors influencing limit values for pine needle litter decomposition: A synthesis for boreal and temperate pine forest systems. Biogeochemistry 2010, 100, 57-73. [CrossRef]

34. Hofrichter, M. Review: Lignin conversion by manganese peroxidase (MnP). Enz. Microb. Technol. 2002, 30, 454-466. [CrossRef]

35. Středová, H.; Středa, T.; Rožnovský, J. Long-term comparison of climatological variables used for agricultural land appraisement. Contrib. Geophys. Geod. 2013, 43, 179-195. [CrossRef]

36. Novotná, J.; Juřička, D.; Burnog, M.; Kotlánová, M.; Kynický, J. Remote Infiltration Areas as a Main Source of Ground Water for Floodplain Forest Without Floods. Acta Univ. Agric. Silvic. Mendel. Brun. 2019, 67, 723-731. [CrossRef]

37. Franzová, M. A Report on the Hydrogeological Survey at Localities Iván̆ I, II, and III; GEOtest, a.s.: Slatina, Czech Republic, 1988. (In Czech)

38. Czech Geological Survey the Database of Geologicaly Documented Objects: Chemical Analysis 2018. Available online: http: / / www.geology.cz/app/gdo (accessed on 14 March 2018). (In Czech).

39. Novotná, J. A Protocol on the laboratory Analysis No. 3201-818/2014; GEOtest, a.s.: Slatina, Czech Republic, 2014. (In Czech)

40. IUSS Working Group. World Reference Base for Soil Rsources 2014, Update 2015; World Soil Resources Reports No. 106; FAO: Rome, Italy, 2015.

41. Zanella, A.; Jabiol, B.; Ponge, J.-F.; Sartori, G.; de Waal, R.; van Delft, B.; Graefe, U.; Cools, N.; Katzensteiner, K.; Hager, H.; et al. A European morpho-functional classification of humus forms. Geoderma 2011, 164, 138-145. [CrossRef]

42. Zbíral, J.; Malý, S.; Čižmár, D. Soil Analysis III: The Unified Methods; ÚKZÚZ Brno: Brno, Czech Republic, 2011. (in Czech)

43. Mehlich, A. Mehlich 3 soil test extractant: A modification of Mehlich 2 extractant. Commun. Soil Sci. Plant Anal. 1984, 15, 1409-1416. [CrossRef]

44. Gömöryová, E.; Vass, D.; Pichler, V.; Gömöry, D. Effect of alginite amendment on microbial activity and soil water content in forest soils. Biologia 2009, 64, 585-588. [CrossRef]

45. RCore Team. A Language and Environment for Statistical Computing; R Foundation for Statistical Computing: Vienna, Austria, 2016.

46. Venables, W.N.; Ripley, B.D. Modern Applied Statistics with S, 4th ed.; Springer: New York, NY, USA, 2002; ISBN 0-387-95457-0.

47. Jandl, R.; Lindner, M.; Vesterdal, L.; Bauwens, B.; Baritz, R.; Hagedorn, F.; Johnson, D.W.; Minkkinen, K.; Byrne, K.A. How strongly can forest management influence soil carbon sequestration? Geoderma 2007, 137, 253-268. [CrossRef]

48. Wäldchen, J.; Schulze, E.-D.; Schöning, I.; Schrumpf, M.; Sierra, C. The influence of changes in forest management over the past 200years on present soil organic carbon stocks. For. Ecol. Manag. 2013, 289, 243-254. [CrossRef]

49. James, J.; Harrison, R. The Effect of Harvest on Forest Soil Carbon: A Meta-Analysis. Forests 2016, 7, 308. [CrossRef]

50. Lal, R. Forest soils and carbon sequestration. For. Ecol. Manag. 2005, 220, 242-258. [CrossRef]

51. Cierjacks, A.; Kleinschmit, B.; Kowarik, I.; Graf, M.; Lang, F. Organic matter distribution in floodplains can be predicted using spatial and vegetation structure data. River Res. Appl. 2010, 27, 1048-1057. [CrossRef]

52. Samaritani, E.; Mitchell, E.A.; Rich, J.; Shrestha, J.; Fournier, B.; Frey, B. Soil bacterial communities and ecosystem functioning change more strongly with season than habitat in a restored floodplain. Appl. Soil Ecol. 2017, 112, 71-78. [CrossRef]

53. Rhoades, J.; Kandiah, A.; Mashali, A.M. The Use of Saline Waters for Crop Production; FAO Irrigation and Drainage Paper 48; FAO: Rome, Italy, 1992.

54. Swenson, H.; Baldwin, H. A Primer on Water Quality: USGS General Interest Publication; USGS: Reston, VA, USA, 1965.

55. Pereira, C.S.; Lopes, I.; Sousa, J.P.; Chelinho, S. Effects of $\mathrm{NaCl}$ and seawater induced salinity on survival and reproduction of three soil invertebrate species. Chemosphere 2015, 135, 116-122. [CrossRef]

56. Yin, S.; Bai, J.; Wang, W.; Zhang, G.; Jia, J.; Cui, B.; Liu, X. Effects of soil moisture on carbon mineralization in floodplain wetlands with different flooding frequencies. J. Hydrol. 2019, 574, 1074-1084. [CrossRef]

57. Mayer, B.; Fritz, P.; Prietzel, J.; Krouse, H. The use of stable sulfur and oxygen isotope ratios for interpreting the mobility of sulfate in aerobic forest soils. Appl. Geochem. 1995, 10, 161-173. [CrossRef]

58. Žalud, Z.; Brotan, J.; Hlavinka, P.; Trnka, M. Trends in temperature and precipitation in the period of 1961-2010 in Žabčice locality. Acta Univ. Agric. Silvic. Mendel. Brun. 2013, 61, 1521-1531. [CrossRef]

59. Fukalová, P.; Středová, H.; Vejtasová, K. Development and Prediction of Selected Temperature and Precipitation Characteristics in Southern Moravia. Acta Univ. Agric. Silvic. Mendel. Brun. 2014, 62, 91-98. [CrossRef] 
60. Rinklebe, J.; Langer, U. Microbial diversity in three floodplain soils at the Elbe River (Germany). Soil Biol. Biochem. 2006, 38, 2144-2151. [CrossRef]

61. Berg, B.; Erhagen, B.; Johansson, M.-B.; Nilsson, M.; Stendahl, J.; Trum, F.; Vesterdal, L. Manganese in the litter fall-forest floor continuum of boreal and temperate pine and spruce forest ecosystems-A review. For. Ecol. Manag. 2015, 358, 248-260. [CrossRef]

62. Trum, F.; Titeux, H.; Ponette, Q.; Berg, B. Influence of manganese on decomposition of common beech (Fagus sylvatica L.) leaf litter during field incubation. Biogeochemistry 2015, 125, 349-358. [CrossRef]

63. Clarholm, M.; Skyllberg, U. Translocation of metals by trees and fungi regulates $\mathrm{pH}$, soil organic matter turnover and nitrogen availability in acidic forest soils. Soil Biol. Biochem. 2013, 63, 142-153. [CrossRef]

64. Meharg, A.A.; Cairney, J.W. Ectomycorrhizas—extending the capabilities of rhizosphere remediation? Soil Biol. Biochem. 2000, 32, 1475-1484. [CrossRef]

65. Rabinovich, M.L.; Bolobova, A.V.; Vasilchenko, L.G. Fungal Decomposition of Natural Aromatic Structures and Xenobiotics: A Review. Appl. Biochem. Microbiol. 2004, 40,1-17. [CrossRef]

66. Bödeker, I.T.; Nygren, C.M.; Taylor, A.F.; Olson, Å.; Lindahl, B.D. ClassII peroxidase-encoding genes are present in a phylogenetically wide range of ectomycorrhizal fungi. ISME J. 2009, 3, 1387-1395. [CrossRef] [PubMed]

67. Hobbie, S.E.; Ogdahl, M.; Chorover, J.; Chadwick, O.A.; Oleksyn, J.; Zytkowiak, R.; Reich, P.B. Tree Species Effects on Soil Organic Matter Dynamics: The Role of Soil Cation Composition. Ecosystems 2007, 10, 999-1018. [CrossRef] 